\title{
Conflicts between cattle ranching and large predators in Venezuela: could use of water buffalo facilitate felid conservation?
}

\author{
Rafael Hoogesteijn and Almira Hoogesteijn
}

\begin{abstract}
The mortality of water buffalo Bubalus bubalis and cattle Bos indicus and B. taurus associated with predation by jaguar Panthera onca and puma Puma concolor, both of which are categorized as Near Threatened on the IUCN Red List, was examined in six Venezuelan ranches. There was significantly higher cattle than buffalo mortality due to predators in all ranches. Compared to buffaloes, cattle had a greater risk of being predated. Variations in monthly predation were observed, with greater cattle mortality during the peak of the rainy season (June-July). Buffalo, but not cattle, displayed defensive behaviour against predators. We suggest that livestock mortality associated with jaguar and puma may be reduced by keeping buffaloes and
\end{abstract}

cattle in the same paddock, or by keeping only buffalo. Reduction of cattle losses is needed to increase tolerance towards jaguar and puma and thus facilitate their conservation. B. bubalis has higher production than cattle in South American flooded tropical grasslands. However, buffalo kept as livestock have two limitations: (1) they may revert to their feral condition if not managed according to the requirements of the species, and (2) some markets pay low prices for buffalo meat or may be reluctant to consume buffalo products.

Keywords Buffalo, cattle, flooded savannah, jaguar, Neotropics, Panthera onca, Puma concolor.

\section{Introduction}

Animosity towards jaguar Panthera onca and puma Puma concolor because of their tendency to prey on cattle is well documented, and habitat loss and hunting in retaliation for cattle (Bos indicus and Bos taurus) predation are the two main threats to jaguar (Rabinowitz, 1986; Quigley \& Crawshaw, 1992; Hoogesteijn et al., 1993; Jackson \& Nowell, 1996; Farrell, 1999; Hoogesteijn \& Crawshaw, 2000; Ginsberg, 2001; Dalponte, 2002; DePaula, 2002; Hoogesteijn et al., 2002; Polisar, 2002; Saenz \& Carrillo, 2002; Scognamillo et al., 2002; Silveira \& Jacomo, 2002; Polisar et al., 2003). Although recent research indicates that jaguar persecution is not directly related to predation problems but is instead linked to cultural values and local perceptions (Conforti \& Azevedo, 2003; Zimmerman et al., 2005), reduction of cattle losses is needed to increase tolerance towards predators. Both jaguar and puma are categorized as Near Threatened on the IUCN Red List (IUCN, 2006).

Conservation of large felids in the seasonally flooded savannahs of Venezuela, Colombia, Bolivia, Brazil and Paraguay involves complex social and ecological issues

Rafael Hoogesteijn and Almira Hoogesteijn (Corresponding author) CINVESTAV, Unidad Mérida, Antigua Carretera Progreso, Km 6, C.P. 97310 , A.P. 73 "Cordemex" Mérida, Yucatán, México. E-mail almirahoo@mda.cinvestav.mx

Received 12 January 2006. Revision requested 4 May 2006 Accepted 10 October 2007. that include at least three factors: (1) private land ownership, (2) livestock as the predominant land use for at least two centuries, and (3) lack of reserved areas sufficiently large and diverse to sustain jaguar populations. Successful conservation of felids must integrate the interactions between livestock grazing, economic constraints, and wildlife management.

Jaguar conservation requires suitable habitat with sufficient prey (Taber et al., 2002) but 71\% of South American savannahs have been converted to croplands (White et al., 2001). Fire is regularly used to increase the quality of native grasses, forests are cleared to increase pasture lands, and natural savannahs are replaced by cultivated pastures with improved yields. In addition, new areas are being cultivated with food crops, especially corn, soy and rice. While many of the ranchers we work with are interested in conservation, the purpose of land ownership is to derive revenues, and economic factors tend to be paramount to conservation interests.

Cattle ranching in Venezuela's flooded savannahs has provided an opportunity to investigate cattle-predator interactions (Hoogesteijn et al., 1993; Farrell, 1999; Polisar, 2000; Scognamillo et al., 2002), and ranchers who raise both buffalo Bubalus bubalis and cattle provide an opportunity to study the mortality of livestock associated with predators. Our preliminary observations suggested that buffalo suffer less predation losses given their ability to defend themselves from jaguars and pumas and to provide a greater economic return than 
cattle under severe flooded conditions. In this study we therefore explored the magnitude of livestock mortality associated with exposure to jaguars and pumas among cattle and water buffalo on ranches in different environments. We examined whether (1) cattle and buffalo have the same risk of being predated by large felids, and (2) if mortality rate is uniform over time or varies seasonally.

\section{Methods}

\section{Selection of ranches}

Our occupation as technical advisors in cattle management allowed us to conduct a retrospective study of cattle and buffalo predation by large cats in ranches where jaguar and puma attacks had been reported. Six ranches were selected based on two mandatory criteria: (1) they bred and raised buffalo and cattle herds; (2) they were located in a region where predation by jaguar and puma had been previously reported. Optional criteria included: (1) ranches were subjected to seasonal flooding conditions, with different types of savannahs; (2) possession of herd records, including total number of domestic animals per species and with probable cause of death determined by a livestock technician or veterinarian with expertise in predation; (3) collection of monthly mortality data. Each ranch had to meet the two mandatory criteria and at least one of the optional criteria. Predation cases were established by visual inspection of the carcass of the killed animal, with photographs of lesions indicative of jaguar or puma attacks.

\section{Statistical analysis}

We used a $\chi^{2}$ test to examine differences in mortality between cattle and buffalo. Any difference in mortality between cattle and buffalo on individual ranches was examined with an odds ratio test. Differences in monthly mortality were assessed after analysis of the distribution (with the Anderson Darling normality test) by calculating the upper limit (with $95 \%$ confidence) of the distribution of mean monthly mortality. A paired $t$-test was used to examine differences in mortality data between 2005 and 2006 on ranch C. Statistical tests were conducted with Statexact v. 5.0.3 (Citel Software Corporation, Cambridge, USA).

\section{Results}

\section{Qualitative analysis}

The characteristics of each ranch are described in Table 1. Four of the six ranches had records of mortality from predation (ranches A, C, E and F), and three also had monthly records of livestock mortality due to jaguars and pumas (ranches A, C and F). Ranch C had monthly records for 2005-2006. Although a no-hunting policy was practised on all ranches, lack of law enforcement and/or geographical isolation meant that ranches still suffered occasional poaching problems. Ranch-specific buffalojaguar interactions are described below.

Ranch $A$ Wildlife is frequently observed. The ranch functions under a semi-extensive system $(70 \%$ of the ranch is under cultivated pasture). Buffaloes are managed in the same paddocks as cattle. Of the 140 recorded deaths in the herd for 2002, 52 were from predation by jaguars or pumas. The greatest predation was recorded in the months of March and June (Fig. 1). The absence of recorded predation in January, April, July and August could be either because no deaths from predation occurred or because the people recording the data failed to recognize those losses.

Ranch B This ranch has an elevated area that does not become inundated. It has typical Trachypogon savannahs and a lower zone flooded by waters of the Orinoco River. The flooded section is only accessible during the dry season when the waters of the Orinoco recede and cattle have access to lush green pastures. Actual cattle and predation numbers could not be obtained from the owners; however, it is in the gallery forest close to the Orinoco River where most cases of predation occurred. Buffalo were introduced and put together with the cattle from 2000 onwards. Jaguar signs such as tracks, predated wildlife carcasses, and scratch marks in trees were seen but no carcasses of predated livestock were observed, although predation had occurred before the introduction of buffaloes.

Ranch C We proposed Buffalo introduction on this ranch in 2001 as a way of maximizing the use of flooded areas and to enhance ranch productivity. The owners introduced 40 buffalo females with calves and a bull into a paddock with the heaviest predation problems where cows were put to calve. After the introduction of buffalo, predation immediately ceased. Elsewhere on this ranch the heaviest predation occurred in June-August 2005 and February-April 2006 (Fig. 1).

Ranch $D$ Jaguars are regularly seen in the forested areas. During 2001, the first year of the introduction of buffalo to this ranch, some buffalo were lost to predation, although no mortality records were kept. During the following year the buffalo herd learned to defend themselves from jaguar attacks, and since 2002 there have been no reports of predation on them. The owners described how buffalo females are so protective of their calves that even a giant anteater Myrmecophaga tridactyla was trampled to death when passing too close to a herd of recently calved females. Neighbouring ranches have reported frequent losses of cattle to jaguar and puma (mainly losses of small and newborn calves to puma). 
Table 1 Habitats of the six selected ranches, with information about the occurrence of poaching, the type of cattle management and the size and composition of the herd in 2002, and also in 2005 and 2006 for Ranch C.

\begin{tabular}{|c|c|c|c|c|}
\hline Ranch & Habitat & Poaching $^{1}$ & Management & Herd $^{2}$ \\
\hline A & Dry savannahs, gallery \& deciduous forest & Probable & $\begin{array}{l}\text { Keep records, including mortality from predation, } \\
\text { \& details of breeding season; attend newborns; } \\
\text { sanitary, genetic and reproductive programmes }\end{array}$ & $\begin{array}{l}2,200 \mathrm{C} \\
220 \mathrm{~B}\end{array}$ \\
\hline B & Dry, flooded \& Trachypogon savannahs & Probable & Basic sanitary programme & Unknown \\
\hline $\mathrm{C}$ & $\begin{array}{l}\text { Flooded savannahs, deciduous \& gallery forest, } \\
\text { rocky hills }\end{array}$ & Probable & $\begin{array}{l}\text { Keep partial records \& details of breeding season; } \\
\text { sanitary programme; attend newborns; } \\
\text { systematic weaning }\end{array}$ & $\begin{array}{l}1,500 \mathrm{CC} \\
40 \mathrm{~B} \\
490 \mathrm{CC}^{3} \\
98 \mathrm{~B}^{3} \\
6,890 \mathrm{CC}^{4} \\
268 \mathrm{~B}^{4}\end{array}$ \\
\hline $\mathrm{D}$ & $\begin{array}{l}\text { Flooded savannahs, tropical dry \& deciduous } \\
\text { forest }\end{array}$ & Probable & $\begin{array}{l}\text { Keep partial records \& details of breeding season; } \\
\text { sanitary programme; attend newborns; } \\
\text { artificial insemination }\end{array}$ & $1,600 \mathrm{~B}$ \\
\hline $\mathrm{E}$ & Open savannahs, tropical \& deciduous forest & Yes & $\begin{array}{l}\text { Keep records of mortality from predation; basic } \\
\text { sanitary programme }\end{array}$ & $\begin{array}{l}200 \mathrm{C} \\
60 \mathrm{~B} \\
120 \mathrm{CC}\end{array}$ \\
\hline $\mathrm{F}$ & $\begin{array}{l}\text { Dry, flooded \& Trachypogon savannahs, rocky and } \\
\text { forested hills, deciduous \& gallery forest }\end{array}$ & Yes & $\begin{array}{l}\text { Keep records, including mortality from predation; } \\
\text { basic sanitary programme }\end{array}$ & $\begin{array}{l}2,250 \mathrm{C} \\
700 \mathrm{~B} \\
210 \mathrm{CC} \\
180 \mathrm{BC}\end{array}$ \\
\hline
\end{tabular}

${ }^{1} \mathrm{All}$ ranches but one have a no-hunting policy but poaching is unavoidable due to remoteness and lack of law enforcement

${ }^{2} \mathrm{C}$, cows; B, buffaloes; CC, cattle calves; BC, buffalo calves

${ }^{3} 2005,{ }^{4} 2006$

Ranch E Poaching occurs frequently, especially on the edges of the ranch. The ranch has a small ecotourism facility, and jaguars and pumas are frequently seen in the area. Buffalo cows were bought from a dairy facility where the animals had been intensively managed, and consequently these buffaloes had no previous experience with large felids. During the first year of introduction (2002) two young calves were predated and a 2-year old animal was severely maimed. Before the introduction of buffalo the cattle herd suffered a predation rate

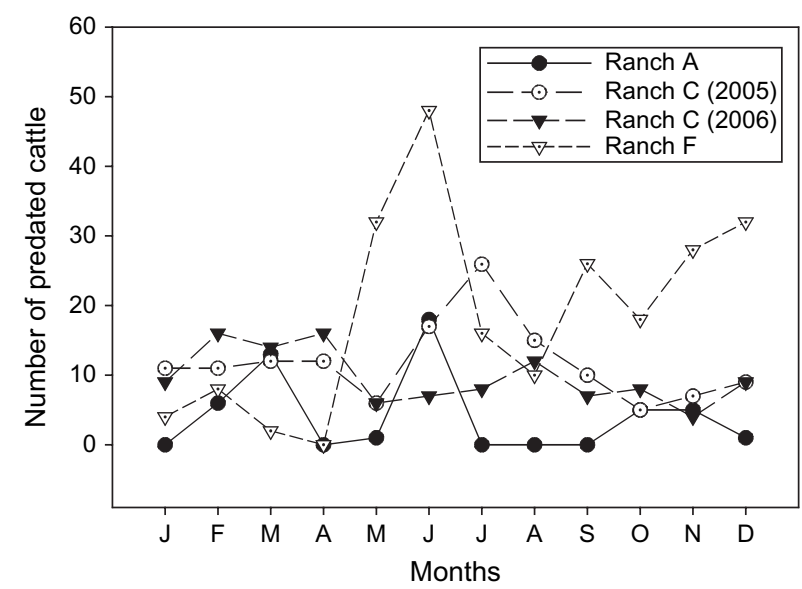

Fig. 1 Number of cattle predated by large felids per month on ranches A and F in 2002 and Ranch C in 2005 and 2006. of 40 calves per year $(23 \%)$. After the introduction of buffalo, predation was reduced to seven calves per year (6\%, data from 2002). No losses from jaguar or puma occurred in the small buffalo herd after the year of their introduction. Together with the introduction of buffalo we issued other recommendations, such as keeping calving animals in paddocks close to housing areas, and keeping sheep and small ungulates penned at night in a closed corral close to the main house. These recommendations reduced overall predation levels of all domestic animals on the ranch.

Ranch $F$ This ranch has a diversity of habitats and a large forested area. Wildlife populations are still rich, although large ungulates such as the Vulnerable Brazilian tapir Tapirus terrestris (IUCN, 2006), white-tailed deer Odocoileus virginianus and peccaries Tayassu sp. have decreased due to poaching. Cattle theft and forest fires occur frequently in the area. With a scarcity of large ungulates and the poor condition of forest outside the ranch, there is heavy predation of cattle by jaguars. There were peaks in monthly predation in May and June and in October-December (Fig. 1). The total number of cattle predated in 2002 was 224 (mostly calves $<3$ months old). One calf and one subadult buffalo were lost to predation in the same year. The calf was born weak, with low weight, and developed severe omphalophlebitis because of worms, and was abandoned by the mother. The subadult got stuck in a ditch and was attacked by two jaguars at night. In both cases the 
attacked buffaloes had a physical impediment that prevented their free movement with the herd, and were therefore not defended by the group.

\section{Quantitative analysis}

Buffalo mortality to predation was $0-5.0 \%$ per ranch, whereas cattle mortality to predation was $1.84-23.5 \%$ $\left(\mathrm{P}<0.0001, \chi^{2}\right.$ test $)$. The odds ratio for each individual ranch indicated that buffalo were at a lower risk of predation than cattle. For instance, the odds of cattle being predated were large in ranch $\mathrm{A}$, and in ranches $\mathrm{E}$ and $\mathrm{F}$ the odds of cattle being predated were 5.8-38.5 times greater than buffalo (Table 2). Because the individual odds ratios were homogeneous $(P \geq 0.10)$, a merged odds ratio could be calculated. The odds of being killed if an animal was a cow were 25.1 times greater than the odds of being killed if the animal was a buffalo (lower and upper 95\% confidence interval 10.6-78.1, $\mathrm{P}<0.005)$. The distribution of mean monthly mortality was normal in ranches $\mathrm{A}, \mathrm{C}$ and $\mathrm{F}(\mathrm{P}>0.05$; Anderson Darling test) and the upper limits for expected monthly mortality (95\% confidence interval) were 11.62 (ranch A), 14.6 (ranch C, 2005), 11.7 (ranch C, 2006) and 28.13 (ranch F). Ranch A's observed mortality was higher than this in March and June. There was no statistically significant difference in monthly mortality between 2005 and 2006 on ranch C. Mortality on Ranch F was higher than expected in May, June and December (Fig. 1).

\section{Discussion}

Our findings suggest that, regardless of habitat and/or husbandry system, predation was greater among cattle B. indicus, B. taurus and their crosses than among buffalo. In four evaluated ranches the odds of cattle

Table 2 Mortality of buffalo and cattle from predation by jaguar and puma on four ranches (see Table 1).

\begin{tabular}{llccc}
\hline Ranch & Species & $\begin{array}{c}\text { Animals } \\
\text { at risk }\end{array}$ & $\begin{array}{l}\text { Animals } \\
\text { killed (\%) }\end{array}$ & $\begin{array}{c}\text { Odds } \\
\text { ratio }\end{array}$ \\
\hline Ranch A & Buffalo & 220 & $0(0)$ & $\sim \infty^{*}$ \\
\multirow{2}{*}{ Ranch C (2005) } & Cattle & 2,148 & $52(2.4)$ & \\
& Buffalo & 98 & 0 & $\sim \infty^{*}$ \\
Ranch C (2006) & Cattle & 4,905 & $153(3.1)$ & \\
& Buffalo & 268 & 0 & $\sim \infty^{*}$ \\
Ranch E & Cattle & 6,890 & $127(1.8)$ & \\
& Buffalo & 57 & $3(5.0)$ & 5.8 \\
Ranch F & Cattle & 153 & $47(23.5)$ & \\
\multirow{2}{*}{ Merged odds ratio } & Buffalo & 698 & $2(0.3)$ & \\
& Cattle & 2,026 & $224(9.9)$ & 38.6 \\
\hline
\end{tabular}

*These values could not be calculated given that predation of buffaloes was 0 . being predated by jaguar or puma were 25 times higher than for buffalo. Predation cases are likely to be higher than the recorded data because small calves may be totally devoured or taken to areas with dense vegetation where they cannot be found.

Qualitative analysis, although anecdotal, shows that buffalo have the same reaction to predators independent of environment or husbandry level. We have observed that when in danger buffalo cows form a circle around their calves, and the bulls go around this circle ready to confront any predator or menace in an active, aggressive way. Cattle, on the other hand, tend to scatter and flee in the presence of a predator, leaving young animals confused and vulnerable to predation. Both B. taurus and $B$. indicus have been raised by humans for at least 7,000 years (Bradley, 2003) with emphasis on domestication in absence of predators. In contrast, there probably exists a long evolutionary relationship between buffalo and the Asian tiger Panthera tigris in which buffalo may have evolved social and defensive behaviour.

The difference in behaviour between buffalo and cattle may be applied to cattle management to avoid predation. Areas with less abundant wildlife populations suffer higher cattle predation rates (Polisar, 2000) and in ranch $\mathrm{E}$, which had the highest predation rate $(23 \%)$, poaching was a recurrent problem. In ranch $C$ predation was reduced drastically in a group of calving cows when 40 buffalo females and one male were introduced into the maternity paddock. Although predation of cattle on this ranch was severe, no predation was observed on the buffalo herd, which has grown steadily since 2001. In another ranch in Venezuela predation immediately decreased in a maternity paddock when cows were replaced by buffalo (Farrell, 1999). In three ranches $(\mathrm{A}, \mathrm{B}$ and $\mathrm{C})$ cattle were put together in the same paddock with buffaloes. Normally the two species tend to remain separate if the area is large (as in ranch B), although cattle and buffalo can learn to share the same space if it is small ( $\leq 100$ ha). Our most important observation is that buffalo presence tends to be sufficient to deter large predators from attacking cattle. Buffalo can be mixed with cattle in chronic, less flooded predation prone areas or reared alone in the most flooded areas where cattle survival and production is compromised by wet conditions. Further studies are required to define how many buffaloes per ha or what cattle to buffalo ratio would be necessary to prevent jaguar and puma predation.

The three ranches (A, C and F) for which we have monthly mortality data had similar patterns of predation (Fig. 1). Increased predation was observed when newborn calves were available and/or when increased contact between cattle and jaguars occurred because of drought or flooded conditions (i.e. when cattle were 
concentrated in restricted areas). Such patterns of predation have been observed elsewhere (Scognamillo et al., 2002). In ranch $A$ there was a slight peak in predation during the month of March, coinciding with the peak of the dry season in which cattle tend to be more concentrated near the few remaining water sources. Calving season peaked in the month of June (cows are exposed to bulls for only 4 months of the year), when another mortality peak was observed. By the nature of the animals predated, and the signs left, most of the kills were newborn calves predated by pumas.

Data for ranch C for 2005-2006 presented a unique opportunity to understand how cattle management can affect predation. New management measures were introduced in 2005, with more buffaloes and cows introduced and a 3-month breeding season implemented, limiting births to January-March for 2006. The pattern of predation during 2005 was the same as for ranches A and F in 2002, with increased predation during the peak of the rainy season. However, in 2006 predation increased slightly, but insignificantly, during February to April. These were the only months in which calves were born. A concentrated birthing season allowed better control of maternity paddocks, decreasing predation by $1.2 \%$, which corresponded to 82 less calves killed by predators.

In ranch $\mathrm{F}$ decreased predation seemed to be associated with high points of flooding that limit contact between cattle and jaguar. To give cattle access to dry land during the rainy months of July and August herds are moved to higher ground close to the main ranch house. When flooding recedes at the start of the dry season (November-December) cattle return to lower ground, including the riverine gallery forests where jaguars roam. Since calves are born throughout the year in ranch $\mathrm{F}$ the continuous presence of young animals encourages continuous predation. Thus, although ranches A, C and F experience similar yearly predation patterns, closer examination reveal distinct ecological and managerial conditions. Such ranch-specific conditions must be taken into account in designing predation control programmes.

Buffalo are highly valued for their productivity, resistance to disease, and longevity. It is generally claimed, however, that buffaloes have a higher environmental impact than cattle because of trampling, overgrazing and overuse of water sources. Such effects do occur in livestock production systems where the carrying capacity of an area is exceeded, thus causing overgrazing, soil compaction and overall production decline (Macedo, 1999; Sheikh, 2002) but are also observed in areas were only cattle are kept. Buffalo are heavier, and tend to use inundated areas more intensively than cattle, and thus carrying capacity needs to be adjusted and managed accordingly. Overgrazing and trampling is a sign that management needs adjustment and is not associated with a particular livestock species.

Bubalis surpasses Bos in its ability to adapt to hot, humid areas of muddy and swampy lands in the neotropics (Regetti et al., 1993; Scannone, 2002; Sheikh, 2002) and because the performance of this species exceeds that of cattle species in similar conditions there is a high demand for buffalo females in Colombia and Venezuela. The differences between cattle and buffaloes have been attributed mainly to the capacity of the buffalo to transform and digest forage of low quality, to resist some infectious diseases and endo- and ectoparasites, and because their growth curve, fertility and longevity is higher than that of cattle in similar conditions (Webster \& Wilson, 1980; Angulo et al., 2005).

In spite of these potential advantages, there are limitations and prerequisites to the use of buffalo for conservation or economic reasons. Buffalo require more intensive supervision and management than cattle. The traditional management method of two round-ups per year, at the beginning and end of the flooding season, in which activities such as corralling, branding, castrating, gynaecological check up, vaccinating, selecting, and slaughtering take place are not recommended. This method is commonly applied to cattle in larger areas of South America such as the Pantanal (Brazil, Bolivia and Paraguay) the Beni (Bolivia) and the Llanos (Venezuela and Colombia), where herds of cattle are left unattended under semi-wild conditions. Under such a management regime buffalo may become feral, a condition that is difficult to reverse. Another limitation is that some local markets do not consume buffalo meat. Whilst the appreciation of buffalo meat varies greatly from country to country, and between regions within countries, the low prices offered for buffalo in some slaughterhouses could limit the interest for this species to ranchers. Nevertheless, given the precociousness, high meat yield, fertility and longevity of the species, even low prices could be accepted as long as a market for the meat exists. However, even if there is little or no market, we consider it may still be a good policy to keep some buffalo to protect cattle, as long as ranchers are willing to manage the species accordingly to its needs.

We consider that the use of buffalo may promote ranchers' tolerance of large felids because buffalo offer an effective and economically productive way to control predation. This tolerance could be used to advance jaguar conservation in areas where implementation of other control methods is impractical or ineffective. Complete removal of cattle or addition of buffalo to existing cattle herds may be a strategy for well adjusted livestock production and felid conservation. Two ranchers in Brazil, one in Bolivia and three in Venezuela are now following our recommendations and, although this 
practice is recent, we have been informed of similar results to those reported here.

\section{Acknowledgements}

We thank the anonymous peer reviewers for comments that improved this paper, A. Rivas and S. Rothenberg for statistical advice, and Rogelio Arenas, Alcira H. de Espinoza, Asdrúbal Hernández Urdaneta, José Antonio Hidalgo, Angelo Pluchino, Alvaro Rotondaro, Hermann Zingg, and Nicomedes Zuloaga for letting us work on their ranches and for supplying data on their cattle. Special thanks go to Richard Savage for the collection and provision of data for ranch $\mathrm{C}$, and to Roberto Ramirez and Rubén Darío Carpio for their careful data collection on ranches A and F, respectively.

\section{References}

Angulo, R.A., Noguera, R.R. \& Berdugo, J.A. (2005) El búfalo de agua (Bubalus bubalis) un eficiente utilizador de nutrientes: aspectos sobre fermentación y digestión ruminal. Http:// www.cipav.org.co/lrrd/lrrd17/6/angu17067.htm [accessed 9 November 2005].

Bradley, D.G. (2003) Genetic hoofprints. Natural History, 112, 36. Conforti, V.A. \& Azevedo, F.C.C. (2003) Local perceptions of jaguars (Panthera onca) and pumas (Puma concolor) in the Iguaçu National Park area, south Brazil. Biological Conservation, 111, 215-221.

Dalponte, J. (2002) Dieta del jaguar y depredación de ganado en el norte del Pantanal, Brasil. In El jaguar en el nuevo milenio (eds A.B. Taber, C.B. Chetkiewicz, R. Medellin, A. Rabinowitz \& K.H. Redford), pp. 209-235. Fondo de Cultura Económica, Universidad Nacional Autónoma de México \& Wildlife Conservation Society, Distrito Federal, México.

DePaula, R. (2002) Effects of human activities on carnivores of the cerrado ecosystem of Brazil. In Proceedings of Carnivores 2002 Conference, pp. 175. Defenders of Wildlife, Washington, DC, USA.

Farrell, L.E. (1999) The ecology of the puma and the jaguar in the Venezuelan Llanos. MSc thesis, University of Florida, Gainesville, USA.

Ginsberg, J.R. (2001) Setting priorities for carnivore conservation: what makes carnivores different? In Carnivore Conservation (eds. J.L. Gittleman, S.M. Funk, D. MacDonald \& R.K. Wayne), pp. 498-523. Cambridge University Press, Cambridge, UK.

Hoogesteijn, R., Boede, E. \& Mondolfi, E. (2002) Observaciones de la depredación de bovinos por jaguares en Venezuela y los programas gubernamentales de control. In El jaguar en el nuevo milenio (eds A.B. Taber, C.B. Chetkiewicz, R. Medellin, A. Rabinowitz \& K.H. Redford), pp. 183-523. Fondo de Cultura Económica, Universidad Nacional Autónoma de México \& Wildlife Conservation Society, Distrito Federal, México.

Hoogesteijn, R. \& Crawshaw, P.G. (2000) Problemas de depredación de felinos en hatos ganaderos. Causas y posibles soluciones. In XVI Cursillo sobre bovinos de carne (eds R. Romero, N.P. Borsoti \& D. Plasse), pp. 205-245. Universidad Central de Venezuela, Maracay, Venezuela.

Hoogesteijn, R., Hoogesteijn, A. \& Mondolfi, E. (1993) Jaguar predation vs jaguar conservation: cattle mortality by felines on three ranches in the Venezuelan Llanos. In Mammals as Predators (eds N. Dunstone \& M.L. Gorman), pp. 391-407. Symposia of the Zoological Society of London, Clarendon Press, Oxford, UK.

IUCN (2006) 2006 IUCN Red List of Threatened Species. IUCN, Gland, Switzerland. Http://www.redlist.org [accessed 20 April 2007].

Jackson, P. \& Nowell, K. (1996) Problems and possible solutions in management of felid predators. Journal of Wildlife Research, 1, 304-314.

Macedo, M.C.M. (1999) Degradação de pastagens: conceitos e metodos de recuperação. In Simposio sustentabilidade da pecuaria de leite no Brasil, pp. 137-150. Embrapa Gado de Leite, Goiania, Brazil.

Polisar, J. (2000) Jaguars, pumas, their prey base and cattle ranching: ecological perspectives of a management issue. PhD thesis, University of Florida, Gainesville, USA.

Polisar, J. (2002) Componentes de la base de presas de jaguar y puma en Piñero, Venezuela. In El jaguar en el nuevo milenio (eds A.B. Taber, C.B. Chetkiewicz, R. Medellin, A. Rabinowitz \& K.H. Redford), pp. 151-182. Fondo de Cultura Económica, Universidad Nacional Autónoma de México \& Wildlife Conservation Society, Distrito Federal, México.

Polisar, J., Maxit, I., Scognamillo, D., Farrell, L.E., Sunquist, M.E. \& Eisenberg, J.F. (2003) Jaguars, pumas, their prey base, and cattle ranching: ecological interpretations of a management problem. Biological Conservation, 109, 297-310.

Quigley, H.B. \& Crawshaw, P.G. (1992) A conservation plan for the Jaguar Panthera onca in the Pantanal region of Brazil. Biological Conservation, 61, 149-157.

Rabinowitz, A. (1986) Jaguar predation on domestic livestock in Belize. Wildlife Society Bulletin, 14, 170-174.

Regetti, J., Rodriguez, R. \& Silva, O. (1993) Retrospectiva histórica y de producción de búfalos en Venezuela. In IX Cursillo sobre bovinos de carne (eds D. Plasse \& N.P. Borsoti), pp. 179-197. Universidad Central de Venezuela, Maracay, Venezuela.

Saenz, J.C. \& Carrillo, E. (2002) Jaguares depredadores de ganado en Costa Rica: un problema sin solución? In El jaguar en el nuevo milenio (eds A.B. Taber, C.B. Chetkiewicz, R. Medellin, A. Rabinowitz \& K.H. Redford), pp. 127-137. Fondo de Cultura Económica, Universidad Nacional Autónoma de México \& Wildlife Conservation Society, Distrito Federal, México.

Sarmiento, G. (1996) Ecología de pastizales y sabanas en América Latina. In Biodiversidad y funcionamiento de pastizales y sabanas en América Latina (eds G. Sarmiento \& M. Cabido), pp. 15-24. CYTED \& CIELAT, Mérida, Venezuela.

Scannone, H. (2002) El búfalo de agua en Venezuela. Venezuela Bovina, 17, 12-17.

Scognamillo, D., Maxit, I., Sunquist, M. \& Farrell, L. (2002) Ecología del jaguar y el problema de la depredación de ganado en un hato de Los Llanos Venezolanos. In El jaguar en el nuevo milenio (eds A.B. Taber, C.B. Chetkiewicz, R. Medellin, A. Rabinowitz \& K.H. Redford), pp. 139-150. Fondo de Cultura Económica, Universidad Nacional Autónoma de México \& Wildlife Conservation Society, Distrito Federal, México.

Sheik, P.A. (2002) The impact of water buffalo and cattle ranching on the lower Amazon floodplain: an ecological and socio-economic comparison. PhD thesis, Pennsylvania State University, State College, USA.

Silveira, L. \& Jacomo, A. (2002) Conservación del jaguar en el centro del cerrado de Brasil. In El jaguar en el nuevo milenio (eds 
A.B. Taber, C.B. Chetkiewicz, R. Medellin, A. Rabinowitz \& K.H. Redford), pp. 437-450. Fondo de Cultura Económica, Universidad Nacional Autónoma de México \& Wildlife Conservation Society, Distrito Federal, México.

Taber, A.B., Cherkiewicz, C.B., Medellín, R., Rabinowitz, A. \& Redford, K.H. (2002) La conservación del jaguar en el nuevo milenio. In El jaguar en el nuevo milenio (eds A.B. Taber, C.B. Chetkiewicz, R. Medellin, A. Rabinowitz \& K.H. Redford), pp. 629-640. Fondo de Cultura Económica, Universidad Nacional Autónoma de México \& Wildlife Conservation Society, Distrito Federal, México.

Webster, C.C. \& Wilson, P.N. (1980) Agriculture in the Tropics. Longman, London, UK.

White, D., Hofman, F., Fujisaka, S. \& Reategui, K. (2001) Will intensifying pasture management in Latin America protect forests - or is it the other way round? In Agricultural Technologies and Tropical Deforestation (eds A. Angelsen \& D. Kaimowitz), pp. 91-111. CABI, Wallington, UK.

Zimmerman, A., Walpole, M.J. \& Leader-Williams, N. (2005) Cattle ranchers' attitudes to conflicts with jaguar Panthera onca in the Pantanal of Brazil. Oryx, 39, 406-412.

\section{Biographical sketches}

Rafael Hoogesteijn is a veterinarian and geneticist for livestock in extensive production conditions and therefore has direct contact with the friction created by expansion of the agricultural frontier. Since 1980 he has compiled data on felids and problems of predation of domestic animals in the Llanos of Venezuela. He is a member of the IUCN/SSC Cat Specialist Group and advisor for the Wildlife Conservation Society's Jaguar Advisory Group. Almira Hoogesteijn has worked on various wildlife conservation and environmental toxicology projects in South America, Europe and North America. She works to find ways to advance domestic animal husbandry and wildlife conservation on privately owned land in Latin America. She currently works on the impact of heavy metals on the environment in the Yucatan Peninsula and works with local NGOs and governmental organizations on livestock-

carnivore problems. 